\title{
The response of a New Guinean avifauna to conversion of forest to small-scale agriculture
}

\author{
- $\quad$ Stuart J. Marsden ${ }^{1}$, \\ - $\quad$ Craig T. Symes ${ }^{2} \&$ \\ - $\quad$ Andrew L. Mack ${ }^{3}$
}

${ }^{1}$ Applied Ecology Group, Department of Environmental and Geographical Sciences, Manchester Metropolitan University, Chester Street, Manchester M1 5 GD, UK

${ }^{2}$ Department of Zoology and Entomology, University of Pretoria, Pretoria 0002, South Africa

${ }^{3}$ Wildlife Conservation Society-Papua New Guinea Program, PO Box 277, Goroka, EHP, Papua New Guinea

[Figures and tables at the bottom of the document]

\section{Abstract}

In comparison with other tropical forest land uses such as selective logging, little is known of the impacts on wildlife of the many forms of small-scale agriculture practised across the tropics. We present density estimates, derived using a point count distance sampling method, for 31 bird species in primary forest, old abandoned gardens and active/recently abandoned gardens at two altitudes in the Crater Mountain Wildlife Management Area (CMWMA), Papua New Guinea. There were clear habitat differences between the six habitat/altitude categories, with, for example, clines in tree sizes and canopy cover from highest values in primary forest to lowest values in current gardens. At lower altitudes, primary forest held highest densities of most species, whereas at higher altitudes, old abandoned gardens had greater densities of many birds, especially insectivores. CANOCO was used to ordinate bird species with respect to major habitat gradient axes. Major axes were associated with differences in bird responses to forest conversion as well as altitudinal differences in species composition. Most important was that several insectivores (especially monarchs, fantails, etc.) formed a cluster of species associated with intact, high-biomass forest. We suggest that most species reacted moderately to habitat changes currently occurring, and this may be due in part to the fact 
that only a small proportion of the landscape at CMWMA has been converted to agriculture (around 13\% may be current or recently abandoned gardens). There were, however, species with comparatively low densities in agricultural habitats and these included several insectivores, the terrestrial Blue Jewel-babbler Ptilorrhoa caerulescens, and three out of four birds of paradise.

Shifting cultivation (including slash-and-burn and gardening) is a major land use and cause of deforestation in tropical regions (Fujisaka et al. 1996, Raman 2001). In fact, Myers (1991) described the landless peasants ('shifted cultivators') practising shifting cultivation as the main agent of tropical forest loss, accounting for at least $60 \%$ of deforestation. Despite the large area of the tropics over which it is practised, the great diversity of agricultural systems, and the debate as to the degree to which such land uses contribute to biodiversity loss (Myers 1991, Halladay \& Gilmour 1995), few papers have assessed the impact on wildlife of the myriad small-scale agricultural systems practised (for birds see the partial review by Dunn 2004; see also Blankespoor 1991, Thiollay 1995, Raman 2001, Naidoo 2004).

Here, we present one of the first multi-species bird studies examining differences in bird abundance between primary forest and small-scale 'garden' agriculture plots. We present population density estimates for 31 forest bird species in primary forest, current and recently abandoned gardens, and old gardens within two altitude bands (432-650 m and 651-935 m) at Crater Mountain Wildlife Management Area (CMWMA), a hillforest region of eastern New Guinea. The last two habitat categories represent small-scale mixed agriculture/agroforestry, the main generic form of forest alteration across much of Papua New Guinea (Levett \& Bala 1994). In CMWMA, agricultural plots are small and exist within an extensive matrix of little-disturbed forest and this mosaic of low-intensity and diverse gardens is rather different from the agricultural landscapes of other studies (Thiollay 1995, Estrada et al. 1997). It is also, however, the type of traditional lowintensity agricultural system that is under threat as a result of agricultural expansion and homogenization in many areas of the tropics (Allen 1985, Thiollay 1995).

Furthermore, the density estimates we present are, in almost every species, the first indications of absolute abundance for birds on New Guinea, so we compare bird densities and reactions to habitat change with those recorded on nearby islands and draw some conclusions as to the likely impact of habitat change on the avifauna as a whole. 


\section{Methods}

\section{Study area and design}

The study took place during April-October 2002 within the 270 000-ha CMWMA, Papua New Guinea (Fig. 1). The CMWMA occupies adjoining portions of Simbu, Eastern Highlands and Gulf Provinces, in the Purari River catchment (Mack \& Wright 1996), and ranges from lowland tropical forest on the Purari River $(50 \mathrm{~m})$ to subalpine scrub on the summit of Crater Mountain (3100 m). Mean annual rainfall ranges from 6500 to $8000 \mathrm{~mm}$ with little seasonal variation in temperature or rainfall (Wright et al. 1997). Data on bird breeding seasons within CMWMA are too scant to gauge fully how the timing of our bird survey fitted in with seasonal breeding patterns. During our survey, nesting, in at least one bird species, was recorded in each of the 7 months (total nesting records $=43$ ), with most frugivore nest records between April and July, and most insectivores/nectarivores between July and September (Symes \& Marsden 2005). At the Crater Mountain Biological Research Station (CMBRS), most breeding appears to occur in two peaks, April-May and September-November with least breeding January-March (A.L.M. unpubl. data).

Our study was restricted to hillforest at altitudes ranging from 432 to $935 \mathrm{~m}$. Data were collected while C.T.S. was based around four settlements of the Pawaiia people: Haia, on the east side of the Nimi River valley; Yabaramaru and Yualaido, recently formed settlements derived from Soliabedo, a now abandoned site referred to by Diamond (1972), on plateaus west of the Rivers Wi and Jei, respectively; and Wara Oo settlement (Toiari Village), situated on the Oo River, south of CMBRS (Fig. 1). The Pawaiia are traditionally semi-nomadic gardeners depending primarily upon Sago Metroxylon sagu. They move widely over their sparsely populated lands, sometimes making temporary housing while they process sago. With the arrival of missionaries in the 1970 s a permanent community arose around the airstrip at Haia - this is their longest permanently settled area. The smaller settlements are more typical of traditional land use, but are still larger and less ephemeral than traditional practice prior to policies of the Australian administration and missionaries that encouraged formation of permanent population centres.

We focused on active gardens, abandoned gardens and primary forest. Forest clearance for small-scale mixed agriculture and agroforestry is the main anthropogenic habitat alteration within the CMWMA (Mack \& Wright 1998). Gardens within CMWMA varied in many respects. Some retained most of their large trees, forming a partial canopy above 
the cleared understorey, whereas others were totally cleared of all vegetation prior to planting. Usually, however, certain trees are left, e.g. Terminalia spp. and Artocarpus cuminis (Breadfruit). The dominant crops were Sweet Potatoes Ipomoea batatas and Sago, although other crops included Peanuts Arachis hypogaea, Cucumber Cucumis sativus, Papaya Carica papaya, Taro Colocasia esculenta, Pineapple Ananas comosus, Banana Musa spp., Coconut Cocos nucifera and Maize Zea mays. Bamboo stands provided cooking, carrying and building material. Most gardens were uninhabited, although some contained small huts for drying firewood or providing shelter for garden workers.

Gardens were generally small, ranging from $0.1-0.2$ ha to around $1-2$ ha, depending on the size of the family group. Close to villages, gardens were sometimes less than $100 \mathrm{~m}$ apart, but further from settlements, they were quite isolated within large areas of littledisturbed forest. Gardens are usually cultivated for 2-3 years before being abandoned or turned over to tree cultivation (e.g. Artocarpus, Pandanus or Terminalia). Sago production takes much longer, with palms taking 15-20 years to mature, and is usually concentrated in particularly boggy areas unsuitable for most other crops. Although garden crops were similar across altitudes, gardening appeared to be more intensive (with a greater proportion of land under agriculture and fewer trees left standing within gardens) around the older settlements within CMWMA, especially around Haia. This intensification reflects higher human population densities around Haia and the relative newness of the Yualaido and Yabaramaru (Soliabedo) and Wara Oo settlements.

\section{Habitat categorization and vegetation sampling}

Bird survey plots were laid out along transects following existing narrow paths or along trails cut especially for this study. Altogether, 226 survey plots were positioned at distances of exactly 200 paces (c. $200 \mathrm{~m}$ ) apart along the transects. Such distances between census points are sufficient to ensure negligible effects on density estimates of birds moving between census points (Buckland et al. 2001). Each survey plot was categorized at the time of the survey based on visual inspection by C.T.S. and on information about current and historical usage provided by local informants (Table 1). The initial habitat categories were:

Primary forest with no visible habitat disturbance (PRIM)

Primary forest with minor disturbance (e.g. small tree removal) (DISTPRIM) 
Garden abandoned $>20$ years previously $(>20$ YR GARD)

Garden abandoned 8-20 years previously (8-20 YR GARD)

Garden abandoned 2-8 years previously (2-8 YR GARD)

Current garden including 5 'homegarden' plots close to houses (GARD)

These were merged into three habitat categories: primary forest (PRIM + DISTPRIM), old gardens ( $>20$ YR GARD $+8-20$ YR GARD) and new gardens (GARD $+2-8$ YR GARD). Although it may seem synthetic to divide the gardens as we did, our \pm 8 years division corresponds roughly to half the time that swidden agricultural land is often left fallow between cultivations (e.g. Andrade \& Rubiotorgler 1994, Fujisaka et al. 1996). Of course such a division may not be entirely justifiable in an ecological sense and this is one reason why we also used a CANOCO to ordinate the survey plots based on their vegetation characteristics rather than their cultivation histories (see later).

To help control for natural altitudinal differences in bird abundance, we divided survey plots into two groups, those above $650 \mathrm{~m}$ and those below $651 \mathrm{~m}$ (104 and 122 plots, respectively). The split bisects the data quite evenly but there is no evidence for distinct floristic boundaries in this altitudinal range, nor does this range typically encompass any major floristic transition (Paijmans 1976, A.L.M. unpubl. data). The proportions of survey plots in the three habitat categories differed between the two altitudinal bands $\left(\chi^{2}=8.8, d f=2, P=0.01\right)$, with more primary forest and fewer new gardens at or below $650 \mathrm{~m}$ than would be expected if land-use covers at the two altitudes were similar (Table 1).

Several habitat measurements were taken at each survey plot. The five largest trees within $20 \mathrm{~m}$ of the plot centre were selected, their diameters at breast height (dbh) measured and their heights estimated using a clinometer. We gained an indication of the recent history of plots by recording the architectures of the five largest trees (Torquebiau 1986, Jones et al. 1995). We noted for each tree whether its first major branch was above (BA) or below (BB) half of its height, and if it 'branched above' whether it had scars from dropped branches below half its height (BASB), or whether it had branches growing vertically from close to its base (BBVG). Tree shape BA indicates trees that probably grew under a closed canopy (undisturbed forest), BB indicates trees that probably grew under an open canopy (disturbed forest or treefall), BASB those that grew under a closing 
canopy (regenerating forest) and BBVG is suggestive of trees growing in heavily altered areas with frequent tree-cutting.

Canopy openness at each plot was assessed on a scale of $1-5$, where $1 \leq 20 \%$ open, $2=21-40 \%, 3=41-60 \%, 4=61-80 \%$ and $5 \geq 80 \%$ open. The volume of creepers present on each of the five trees was assessed visually: $0=$ no creepers, $1=$ few creepers present on main stem and branches, $2=$ creepers covering $50-75 \%$ of tree and $4=$ creepers covering $>75 \%$ of tree. The altitude of each plot was estimated to the nearest $10 \mathrm{~m}$ from maps (1:100 000, Crater Sheet no. 7984 and Karimui Sheet no. 7884, PNG National Mapping Bureau reprinted from Royal Australian Survey Corps, 1977).

Useful indications of the proportion of the landscape within the study area that was turned over to small-scale agriculture can be gained from two sources. First, we set up our sampling plots in an attempt to reflect best the land-use types within the study area by positioning them every 200 paces along transects. Of the 226 survey plots set up, 13.7\% were described at the time of the survey as being new gardens (active within the last 8 years), $40.3 \%$ as $>8$-year-old abandoned gardens and the remaining $46 \%$ as primary forest. In addition, we set up, for a related project, a series of 144 bird survey plots, arranged in a grid running from the Haia airstrip out away from the village. Survey plots were positioned within this $2.3 \times 0.3-\mathrm{km}$ grid, either $50 \mathrm{~m}$ apart (short axis) or $100 \mathrm{~m}$ apart (long axis). The grid abutted part of the area used in the main study but because it was relatively close to the village of Haia, it may overestimate the proportion of agricultural land in the area. Of the 125 survey plots within the grid that were not classified as village, $12.8 \%$ were classified as new gardens ( $<8$ years old), $53.6 \%$ as $>8$ year-old gardens and $33.6 \%$ as primary forest.

\section{Bird survey methods}

Birds were counted using a variable circular plot method (Jones et al. 1995). Birds were counted at each plot twice, once between 06:00 and 11:00 h, and once on a different day between 11:00 and 14:00 h. No bird surveys were undertaken during persistent rain or strong wind. We fixed the count period at $10 \mathrm{~min}$ and allowed no 'settling down' period prior to recording. Survey plots were approached very stealthily and any birds that were flushed, or that otherwise moved off from around the survey point on the recorder's arrival, were counted as being present during the count period, and the distance from their initial position to the centre of the plot estimated. The horizontal distance to each contact with a perched bird/bird flock was estimated to the nearest $1 \mathrm{~m}$. Although birds were sometimes recorded at distances greater than $50 \mathrm{~m}$ from the plot's central point, such records contribute very little to density estimates produced using DISTANCE, mainly 
because the area surveyed at such distances is very large (Buckland et al. 2001). In fact, during the analysis phase, the most distant records are truncated as a matter of course to improve model fit (see below). Similarly, estimates of distance (to the nearest $1 \mathrm{~m}$ ) to contacts $>50 \mathrm{~m}$ from the recorder are likely to be less accurate than those to contacts close to the recorder. However, again, random inaccuracies in distance estimations to distant birds are not important as these records contribute so little to the density estimation process (Buckland et al. 2001). All records of birds in flight at survey plots, except those which took flight in response to recorder presence, were excluded from the analysis following the rationale of Marsden (1999).

C.T.S. conducted all bird surveys accompanied by a trained local observer (TLO). The TLOs (see Acknowledgements) had extensive bird identification training and experience and had previous experience working with scientists. Prior to bird surveys, C.T.S. underwent extensive training in bird identification, bird vocalizations using bird tapes, distance estimation and other aspects of the fieldwork. All birds at survey plots were counted except for swiftlets and nocturnal birds.

\section{Data analysis}

For the five largest trees, we calculated the mean and standard deviation of dbhs (the latter measure gives some indication of the variability in sizes of trees forming the canopy within the plot). The standard deviations of dbhs were converted to coefficients of variation (sd as a percentage of the mean). We also calculated the mean tree height and counted the numbers of primary forest tree architectures and regenerating tree architectures.

Differences between vegetation measures across the six habitat types were tested using one-way ANOVAs, as we aimed to detect differences between all six sites rather than describe the effects of habitat type and altitude separately. For mean dbh, coefficient of variation (cv) of dbh and mean height, parametric ANOVAs were used with Tukey's HSD post-hoc tests. For the other habitat parameters, we used the non-parametric KruskalWallis test with Dunn's post-hoc tests.

For analyses of species diversity and overall encounter rates, we included all bird species recorded at plots (i.e. no truncation was done). True species richness in each of the six habitat type/altitudes was estimated using a rarefaction technique (Colwell \& Coddington 1994). We used EstimateS v.6 (http://0-

viceroy.eeb.uconn.edu.innopac.up.ac.za:80/estimates) with 50 randomizations (no replacement) and retained estimates of species richness derived from the Abundance-base 
Coverage Estimator (ACE; Chazdon et al. 1998) and a first-order jackknife with associated standard deviation.

We calculated encounter rates and percentage standard errors for individual bird species using the DISTANCE 3.5 software (http://0-www.ruwpa.stand.ac.uk.innopac.up.ac.za:80/distance). For the calculation of encounter rates, data were not right-hand truncated. We calculated density estimates using the DISTANCE 3.5 program using only perched records (Marsden 1999). For density estimation data were right-hand truncated for each species prior to analysis, omitting the furthest $5-10 \%$ of records (Buckland et al. 2001). However, during exploratory data analysis using DISTANCE, a larger percentage of distant records was truncated up to a maximum of $20 \%$ if it improved model fit. Data were, in most cases, pooled across the habitat types to produce a single detection function for each species at each altitude [checking of Akaike's Information Criterion (AIC) values for the pooled detection function with AICs from habitat-specific analyses determined whether or not habitats should be combined]. In cases where a single function was modelled, data were post-stratified to give habitatspecific density estimates (Buckland et al. 2001).

Data were entered as clusters in ungrouped format. For aural contacts where flock size could not be ascertained, we substituted the mean flock-size value for those contacts where we were certain of flock size. In addition, the effect of distance from recorder on flock size was considered using the size bias option, with flock sizes adjusted if regressions were significant at $P<0.10$. The choice of detection function and series expansions was made by comparing AIC values between models. We present density estimates for only a subset of all species counted because many species were recorded too infrequently to make reliable density estimates in particular habitats. We restrict our density estimation to species recorded more than 50 times overall.

To identify patterns of bird community variation across the survey plots and to relate these to the main axes of habitat variability, we used the canonical correspondence analysis or CANOCO (ter Braak 1986) of MVSP (Kovach Computing Services: $\mathrm{http}$ ://www.kovcomp.co.uk/mvsp). Canonical correspondence analysis (CCA) is a multivariate direct gradient method that, in our case, ordinates the bird species or plots at which they were recorded with respect to environmental axes defined by the habitat and physical recordings made at the plots. We considered the presence or absence of each bird species at either visit to each of the 226 survey plots and counted birds as present at survey plots if they were recorded less than $50 \mathrm{~m}$ from the plot's central point. We excluded those bird species that were recorded at fewer than five survey plots but did not subsequently downweight rare species in the analysis. Fourteen continuous habitat 
variables were entered into the analysis. CCA was performed using the reciprocal averaging method of Hill (1973). We employed the default 'by species' scaling method as our main interest was in the ordination of individual species with respect to one another and the environmental variables, rather than the ordination of individual plots. The ordination of habitat variables on the first two axes of the CANOCO was plotted along with the species scores of those 78 species included in the analysis.

\section{Results}

\section{Habitat characteristics of land uses/altitudes}

There were clear differences in the measured habitat features between the six habitat/altitude categories (Table 2). Tree sizes were greatest and canopy cover fullest in lower altitude primary forest. In both altitudinal classes, tree sizes and canopy covers were greatest in primary forest and smallest in current garden. Tree sizes in primary forest at higher altitudes were greater than in other high-altitude habitats, but trees were smaller than in lowland primary forest, similar to those in lowland old garden and higher than those in lowland new garden. Tree sizes in new gardens were similar across altitudes. Tree size diversity was greatest in low-altitude gardens currently in use.

Primary forests showed the highest proportion of trees with primary forest architecture, although old gardens at higher altitudes retained many primary forest tree shapes. Regenerating tree architectures were common only at lower altitudes, suggesting a different pattern of historical disturbance than at higher levels of CMWMA. Finally, although abandoned gardens seem to have reacquired their creeper cover, there was a clear loss of creepers around large trees in current gardens at both altitudes (Table 2).

\section{Bird species richness and overall abundance}

Excluding aerial records, and records of birds only identified to genus, there were 4332 records of birds of 135 species. Altogether, $86 \%$ of birds recorded were heard only. Overall encounter rates (species combined) differed across the six habitat/altitude classes $\left(F_{5,412}=24.5, P<0.001\right)$. Of 116 species recorded in the standardized subsample of plots, 29 species were exclusive to habitats at lower altitudes, only eight were exclusive to higher altitudes and 79 species were shared. The number of species exclusive to old gardens was low (three at lower altitudes and none at higher altitudes), but many species were found in old gardens at either or both altitudes (Table 3). 


\section{Bird density estimates}

Density estimates for 31 species recorded on 50 or more occasions (not necessarily at 50 different census points) are shown in Table 4 . Nine of the species had density estimates of $>50$ per $\mathrm{km}^{2}$ in at least one habitat/altitude type. Altogether, birds achieved densities $>$ 50 per $\mathrm{km}^{2}$ in 24 of the habitat/altitude types (15 in lower altitude plots and nine in higher altitude plots). Notable were density estimates for Tawny-breasted Honeyeater Xanthotis flaviventer ( $>50$ in all six habitat/altitude types), Scrub White-eared Meliphaga Meliphaga albonotata ( $>50$ in all but one habitat/altitude type), Papuan Flowerpecker Dicaeum pectorale ( $>50$ in all three lowland habitat types) and Raggiana Bird of Paradise Paradisaea raggiana ( $>50$ in both garden habitats at higher altitudes).

In the lower altitudinal band, 14 species had highest or joint highest densities in primary forest, five in old gardens and 13 in new gardens. Density was lowest or joint lowest in primary forest for nine species, in old gardens for 12 species and in new gardens for 11 species. The pattern was rather different at higher altitudes where only six species had highest or joint highest densities in primary forest, 15 in old gardens and ten in new gardens. Density was lowest or joint lowest in primary forest for 18 species, in old gardens for just three species and in new gardens for 11 species. The proportions of species with the highest densities in the three habitats differed between the altitudes $\left(\chi^{2}=8.6, d f=2, P=0.01\right)$ as did the proportions of species having the lowest densities in the three habitats $\left(\chi^{2}=8.4, d f=2, P=0.02\right)$. Primary forest was more 'preferred' at lower altitudes, and old gardens at higher altitudes, than expected if preferences were unaffected by altitude.

\section{Bird community analysis}

Axes 1 and 2 of the CANOCO were correlated significantly with the environmental axes $(r>0.78, P<0.001)$. All individual environmental variables except gradient, standard deviation of tree heights and creeper cover were significantly correlated with one or other of Axes 1 and 2. There were, of course, some strong correlations between the recorded habitat variables (Fig. 2a). Tree heights and girths, and number of buttress roots and creepers were all positively autocorrelated whereas these variables were strongly negatively correlated with canopy gaps and the secondary forest architectures (branching below and branching below with vertical growth). Altitude and slope correlated little with the above variables but showed strong correlations with Axis 2 scores (and were negatively correlated with the tree architecture that is characteristic of regenerating forest). 
The bird species ordination showed some clear patterns. Species such as Brown Cuckoodove Macropygia amboinensis, Dollarbird Eurystomus orientalis, White-shouldered Fairy-wren Malurus alboscapulatus, White-bellied Thicket Fantail Rhipidura leucothorax, Mimic Meliphaga Meliphaga analoga, Helmeted Friarbird Philemon buceroides and Streak-headed Mannikin Lonchura tristissima were all associated with the most open-canopied/degraded areas. The ordination also identified some species associated strongly with the higher altitude areas: these included Pheasant Pigeon Otidiphaps nobilis, Chestnut-backed Jewel-babbler Ptilorrhoa castanonotus, Rusty Whistler Pachycephala hyperythra and White-eared Catbird Ailuroedus buccoides.

Strongly associated with regenerating (older) secondary forests at low altitudes were a cluster of parrots and pigeons: Ornate Fruit-dove Ptilinopus ornatus, Pinon Imperial Pigeon Ducula pinon, Red-flanked Lorikeet Charmosyna placentis and Buff-faced Pygmy-parrot Micropsitta pusio. Perhaps most important in conservation terms are the species that are associated with the high-biomass, primary forests (bottom-left quadrant of the ordination in Fig. 2). There is a preponderance of insectivores in this quadrant, including Blue Jewel-babbler Ptilorrhoa caerulescens, Chestnut-bellied Fantail Rhipidura hyperythra, Northern Fantail Rhipidura rufiventris, Frilled Monarch Arses telescophthalmus, Spot-winged Monarch Monarcha guttula, Golden Monarch Monarcha chrysomela, Olive Flycatcher Microeca flavovirescens and Pygmy Honeyeater Oedistoma pygmaeum.

\section{Discussion}

\section{Species reactions to habitat change}

Many species were tolerant of the small-scale forest changes found within CMWMA. Seventeen of the 31 species had higher density estimates in one of the lowland garden habitats than in the lowland primary forest and 25 species had higher density estimates in one of the garden habitats than in primary forest at higher altitudes. The majority of species occurred at densities similar to those in primary forest in at least one of the two garden habitats and this is important as it means they can utilize at least some parts of the anthropogenic landscape in numbers at a given time. Only four species, Rusty Mousewarbler Crateroscelis murina, Magnificent Riflebird Ptiloris magnificus, King Bird of Paradise Cicinnurus regius and Magnificent Bird of Paradise C. magnificus, had estimated densities in both lowland anthropogenic habitats less than $50 \%$ of those in lowland primary forest. In the higher altitude areas, just one species (Magnificent 
Riflebird) had density estimates in gardens not exceeding $50 \%$ of the primary forest value. Of course, we are not sure that the apparent tolerance of the 31 (common) species extends to the rarer species within the avifauna, but at least modest anthropogenic modification that has occurred at the site has not been detrimental to all birds.

The birds of paradise (Paradisaeidae), although found in closed-canopy rainforest and including some species that are specialized frugivores (Frith \& Beehler 1998), have been considered to be reasonably habitat tolerant, occurring in forest edge, secondary forest, disturbed forest near villages and abandoned gardens (Frith \& Beehler 1998, Heads 2001). At CMWMA, they did occur in disturbed habitats but were among the species least tolerant of forest change - only one species from four tolerated habitat change well. Although low levels of hunting of birds-of-paradise occurs within CMWMA, we feel that the lower densities recorded for most species in gardens reflect more their habitat associations than differences in hunting pressure. Some of the species occurred at reasonably high densities, especially King Bird of Paradise (5-65 per $\mathrm{km}^{2}$ ) and Raggiana Bird of Paradise (15-70 per $\mathrm{km}^{2}$ ), but Magnificent Bird of Paradise, and especially Magnificent Riflebird (0-15 per $\mathrm{km}^{2}$ ), appear to be rarer. The density of King Bird of Paradise in lower altitude forest at CMWMA was similar to the estimate of Bell (1982) for this species in lowland rainforest at Brown River (60 individuals per $\mathrm{km}^{2}$ ), but was lower for Raggiana Bird of Paradise (his estimate was 100 per $\mathrm{km}^{2}$ ) and Magnificent Bird of Paradise (his estimate was 60 per $\mathrm{km}^{2}$ ).

Bird reactions to small-scale agriculture appeared generally to be better at higher elevations than at lower elevations. Gardens in the higher parts of the study site were older and more densely packed than those lower down, so the pattern is unlikely to be an artefact of lower impact gardening at higher elevations. It is possible that the small-scale forest changes of the sort that occur at higher elevations within the area of our study might benefit some (particularly insectivorous) birds by, for example, creating areas of dense understorey vegetation, breaking up the canopy, and producing more edges or a finer-scaled mosaic of microhabitats (Goldblum 1997, Vetaas 1997, Huertas \& Diaz 2001, Grau 2002). More detailed studies that measure various habitat parameters are needed in order to understand better why birds respond as they do to anthropogenic modifications.

Although species least 'tolerant' of garden habitats or most associated with intact forest came from disparate groups, insectivores were well represented. They include two fantails (Chestnut-bellied and Northern), several monarchs and flycatchers, Rusty Mousewarbler and Little Shrike-thrush Colluricincla megarhyncha. Undoubtedly, there are other insectivores that are also intolerant of garden habitats but that were too infrequently 
recorded to estimate densities reliably. For example, Blue Jewel-babbler was recorded 29 times in lowland primary forest, and five times in lowland old gardens, but was not recorded in the other habitats - this is a largely terrestrial insectivore, which, although described as common by Beehler et al. (1986), may be sensitive to forest change in the lowlands (Driscoll 1985).

\section{Comparisons with other regions}

The density estimates for New Guinea's birds in primary forest are broadly comparable with those, derived using similar methods, for birds from nearby Wallacea. The majority of birds at CMWMA, as on islands to the west in Wallacea, have densities estimated at 1-50 individuals per $\mathrm{km}^{2}$, with only two species achieving densities greater than 100 per $\mathrm{km}^{2}$. The most common species on Wallacean islands are reported to occur at densities of up to 500 or even 1000 per $\mathrm{km}^{2}$ (Jones et al. 1995, Marsden 1998, Riley 2002) and it may be that CMWMA lacks such superabundant species. Although the density estimates themselves may be different, the taxonomic groups attaining the highest densities are similar (e.g. sunbirds and flowerpeckers).

Studies elsewhere have found some serious reductions in the abundance of species following forest alteration. Thiollay (1995) found that over half of forest bird species declined or disappeared within three agroforestry types (permanent 'garden forests' dominated by Rubber Hevea brasiliensis, Durian Durio zibethinus and Damar Shorea javanica) in Sumatra. Driscoll (1985) found diversity and density lower in plantation forest in lowland Papua New Guinea and lower densities of understorey birds in regrowth forest. Although there are certain affinities in the sorts of species that 'declined' both in Sumatra and in CMWMA (large frugivores, some insectivores, terrestrial foragers), the scale of the declines was certainly much higher than those reported from Sumatra, and in small-scale agriculture (Raman 2001, Dunn 2004, Naidoo 2004, contra Andrade \& Rubiotorgler 1994) and selective logged forests elsewhere (Lambert 1992, Thiollay 1992, Marsden 1998).

We are not suggesting that the New Guinea avifauna is predisposed to being tolerant of these types of habitat change. Within our study area, most land has not been developed, and remains as pristine or little-disturbed forest. We believe that it is the small proportion of forest converted to agriculture at CMWMA and the close proximity of gardens to pristine forest that has helped allow birds to survive in at least some of the anthropogenic land uses. Such a mosaic of habitats as seen at CMWMA may benefit some species, or at least allow them to persist temporarily at high densities. On nearby New Britain, gardens contained higher fruit/flower densities than primary forest, attracting large parrot and 
hornbill populations from adjacent primary forest, where nest-site densities were highest (Marsden \& Pilgrim 2003).

\section{Conservation implications}

Although bird populations at CMWMA, as over much of Papua New Guinea, remain healthy, the agricultural intensification and extensification occurring in parts of Papua New Guinea and Irian Jaya (Levett \& Bala 1994) are a cause for concern. Currently, agricultural plots are reasonably small and set amongst large tracts of intact primary forest, but a threshold may soon be reached where there is too little remnant forest, and where agricultural plots are too extensive and homogeneous to allow use of the landscape by birds as we see at CMWMA. The impact of such land-use intensification on tropical birds is poorly known generally, and the ecology of New Guinea's birds is too little understood to make realistic predictions as to future bird population trends. In comparison with areas such as the Philippines and the Lesser Sundas (Stattersfield et al. 1998), the New Guinea avifauna remains in reasonable shape (BirdLife International 2004), but high levels of local bird endemism coupled with increasing rates of forest change mean that more New Guinea species are likely to become threatened in the near future. Although not seen now as major targets for reactive conservation-based data collection, quantitative data on the abundance and habitat requirements of birds are needed from key regions to allow conservationists a chance to be proactive in addressing the conservation needs of particularly vulnerable species.

The project was funded by the North of England Zoological Society and we thank Dr Roger Wilkinson for various help. The National Research Institute of Papua New Guinea (NRI) is acknowledged for facilitating our research, and the Research and Conservation Foundation of Papua New Guinea (RCF) and Wildlife Conservation Society (WCS Papua New Guinea Program) are thanked for their support throughout the study. We are particularly grateful to Ross Sinclair and Deb Wright (WCS) for their invaluable help and kindness throughout the project. The Pawaiia people of the area, and especially C.T.S.'s guides (TLOs), Ijenepe, Rocksy and Sam, and their families, are thanked for their hospitality, kindness and support. 


\section{References}

-

Allen, B.J. 1985. Dynamics of fallow successions and introduction of robusta coffee in shifting cultivation areas in the lowlands of Papua New Guinea. Agroforestry Systems 3: 227-238.

-

Andrade, G.I. \& Rubiotorgler, H. 1994. Sustainable use of the tropical rain-forest evidence from the avifauna in a shifting-cultivation habitat mosaic in the Colombian Amazon. Conserv. Biol. 8: 545-554.

Beehler, B.M., Pratt, T.K. \& Zimmerman, D.A. 1986. Birds of New Guinea. : Princeton University Press.

-

Bell, H.L. 1982. A bird community of lowland rainforest in New Guinea. 1. Composition and density of the avifauna. Emu 82: 24-41.

BirdLife International. 2004. Threatened Birds of the World 2004 . CR-ROM. : BirdLife International.

Blankespoor, G.W. 1991. Slash-and-burn shifting agriculture and bird communities in Liberia, west Africa. Biol. Conserv. 57: 41-71.

-

ter Braak, C.J.F. 1986. Canonical correspondence-analysis - a new eigenvector technique for multivariate direct gradient analysis. Ecology 67: 1167-1179.

Buckland, S.T., Anderson, D.R., Burnham, K.P., Laake, J.L., Borchers, D.L. \& Thomas, L. 2001. Introduction to Distance Sampling: Estimating Abundance of Biological Populations. : Oxford University Press.

Chazdon, R.L., Colwell, R.K., Denslow, J.S. \& Guariguata, M.R. 1998. Statistical methods for estimating species richness of woody regeneration in primary and secondary rain forests of NE Costa Rica . In Dallmeier, F. \& Comiskey, J.A. (eds) Forest Biodiversity Research, Monitoring and Modeling: Conceptual Background and Old World Case Studies: 285-309. : Parthenon Publishing.

-

Colwell, R.K. \& Coddington, J.A. 1994. Estimating terrestrial biodiversity through extrapolation. Phil. Trans. Roy. Soc. Lond. B 345: 101-118.

Diamond, J.M. 1972. Avifauna of the Eastern Highlands of New Guinea. Publ. Nuttall Orn. Club 12: 1-438.

-

Driscoll, P.V. 1985. The Effects of Logging on Bird Populations in Lowland New Guinea Rainforest. PhD dissertation, . 
Dunn, R.R. 2004. Managing the tropical landscape: a comparison of the effects of logging and forest conversion to agriculture on ants, birds, and lepidoptera. For. Ecol. Man. 191: 215-224.

Estrada, A., Coates-Estrada, R. \& Meritt, D.A. Jr 1997. Anthropogenic landscape changes and avian diversity at Los Tuxtlas, Mexico. Biodiv. Conserv. 6: 19-43.

Frith, C.B. \& Beehler, B.M. 1998. Birds of Paradise. : Oxford University Press.

Fujisaka, S., Hurtado, L. \& Uribe, R. 1996. A working classification of slash-and-burn agricultural systems. Agroforestry Systems 34: 151-169.

Goldblum, D. 1997. The effects of treefall gaps on understory vegetation in New York State. J. Veg. Sci. 8: 125-132.

Grau, H.R. 2002. Scale-dependent relationships between treefalls and species richness in a Neotropical montane forest. Ecology 83: 2591-2601.

Halladay, P. \& Gilmour, D.A. (eds) 1995. Conserving Biodiversity Outside Protected Areas: the Role of Traditional Agroecosystems. : IUCN.

-

Heads, M. 2001. Birds of paradise, biogeography and ecology in New Guinea: a review. J. Biogeog. 28: 893-925.

Hill, M.O. 1973. Reciprocal Averaging: an eigenvector method of ordination. J. Ecol. 61: 237-249.

Huertas, D.L. \& Diaz, J.A. 2001. Winter habitat selection by a montane forest bird assemblage: the effects of solar radiation. Can. J. Zool. 79: 279-284.

-

Jones, M.J., Linsley, M.D. \& Marsden, S.J. 1995. Population sizes, status and habitat associations of the restricted-range bird species of Sumba, Indonesia. Bird Conserv. Int. 5: 21-52.

Lambert, F.R. 1992. The consequence of selective logging for Bornean lowland forest birds. Phil. Trans. Roy. Soc. Lond. B 335: 443-457.

Levett, M. \& Bala, A. 1994. Agriculture in Papua New Guinea . In Sekhran, N. \& Miller, S. (eds) Papua New Guinea Country Study on Biological Diversity . A report to the United Nations Environmental Program: 125-153. : Department of Environment and Conservation Resource Centre , and Nairobi, Kenya: Africa Centre for Resources and Environment.

Mack, A.L. \& Wright, D.D. 1996. Notes on occurrence and feeding of birds at Crater Mountain Biological Research Station, Papua New Guinea. Emu 96: 89-101. 
Mack, A.L. \& Wright, D.D. 1998. The Vulturine Parrot, Psittrichas fulgidus, a threatened New Guinea endemic: notes on its biology and conservation. Bird. Conserv. Int. 8: 185194.

Marsden, S.J. 1998. Changes in bird abundance following selective logging on Seram, Indonesia. Conserv. Biol. 12: 605-611.

-

Marsden, S.J. 1999. Estimation of parrot and hornbill densities using a point count distance sampling method. Ibis 141: 377-390.

Marsden, S.J. \& Pilgrim, J.D. 2003. Factors influencing the abundance of parrots and hornbills in disturbed and pristine forests on New Britain, PNG. Ibis 145: 45-53.

Myers, N. 1991. Tropical forests - present status and future outlook. Climatic Change 19: $3-32$.

-

Naidoo, R. 2004. Species richness and community composition of songbirds in a tropical forest-agricultural landscape. Anim. Conserv. 7: 93-105.

Paijmans, K. 1976. New Guinea Vegetation. : Australian National University Press.

-

Raman, T.R.S. 2001. Effect of slash-and-burn shifting cultivation on rainforest birds in Mizoram, northeast India. Conserv. Biol. 15: 685-698.

Riley, J. 2002. Population sizes and the status of endemic and restricted-range bird species on Sangihe Island, Indonesia. Bird Conserv. Int. 12: 53-78.

Stattersfield, A.J., Crosby, M.J., Long, A.J. \& Wege, D.C. 1998. Endemic Bird Areas of the World: Priorities for Biodiversity Conservation. : BirdLife Conservation Series no. 7.

-

Symes, C.T. \& Marsden, S.J. 2005. Notes on breeding of Salvadori's Teal Anas waiguiensis and other birds in Crater Mountain Wildlife Management Area, Papua New Guinea. Bull. Br. Orn. Club 125: 11-27.

Thiollay, J.M. 1992. Influence of selective logging on bird species diversity in a Guianan rain forest. Conserv. Biol. 6: 47-63.

Thiollay, J.M. 1995. The role of traditional agroforests in the conservation of rain forest bird diversity in Sumatra. Conserv. Biol. 9: 335-353.

-

Torquebiau, E.F. 1986. Mosaic patterns in Dipterocarp rain forest in Indonesia and their implications for practical forestry. J. Trop. Ecol. 2: 301-325.

Vetaas, O.R. 1997. The effect of canopy disturbance on species richness in a central Himalayan oak forest. Plant Ecol. 132: 29-38. 
Wright, D.D., Jessen, J.H., Burke, P. \& de Silva Garza, H.G. 1997. Tree and liana enumeration and diversity on a one-hectare plot in Papua New Guinea. Biotropica 29: 250-260.

\section{Figures and tables}

Figure 1. Map showing the position of Crater Mountain Wildlife Management Area (CMWMA) and the locations of study sites within it.

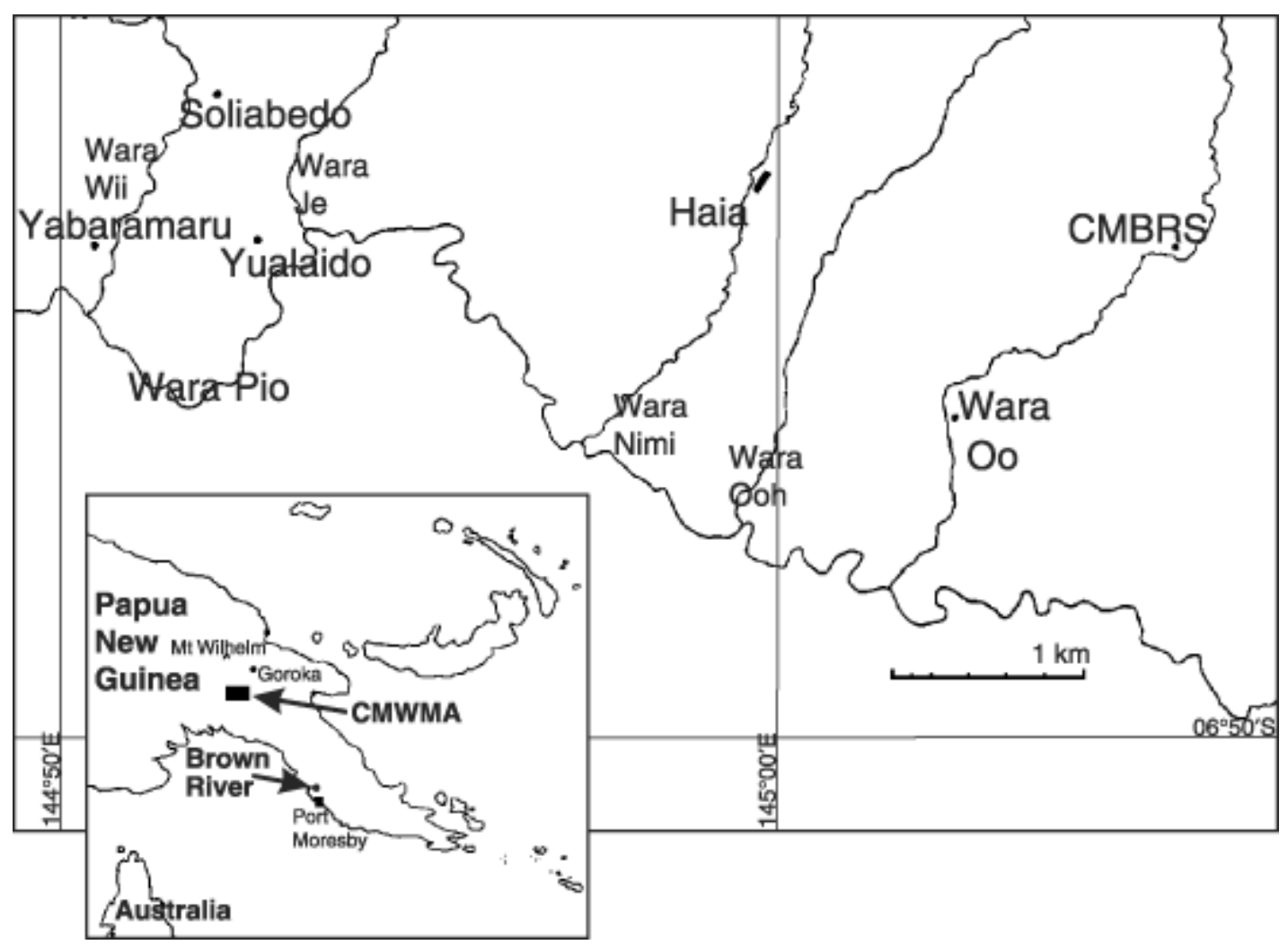

Figure 2. Ordination of habitat variables (a) and bird species (b) on the first two canonical axes from CANOCO. Variables are described in the Methods section: BASB, branching above with scars below; BB, branching below; BBVG, branching below with vertical growth; BA, branching above. In (b), those species with high or low scores on either/both axis are labelled as follows: WSFW, White-shouldered Fairy-wren; WBTF, White-bellied Thicket Fantail; VT, Varied Triller; HF, Helmeted Friarbird, SHM, Streak- 
headed Mannikin; BCD, Brown Cuckoo-dove; MM, Mimic Meliphaga; RCP, Redcheeked Parrot; SBM, Spot-breasted Meliphaga; WEC, White-eared Catbird; RW, Rusty Whistler; CBJB, Chestnut-backed Jewel-babbler; YBL, Yellow-bellied Longbill; PP, Pheasant Pigeon; STF, Sooty Thicket-fantail; M,R Magnificent Riflebird; WFD, Wompoo Fruit-dove; PH, Pygmy Honeyeater; CBF, Chestnut-bellied Fantail; NF, Northern Fantail; GM, Golden Monarch; SWM, Spot-winged Monarch; FM, Frilled Monarch; OF, Olive Flycatcher; BJB, Blue Jewel-babbler; BFPP, Buff-faced Pygmyparrot; OFD, Ornate Fruit-dove; PIP, Pinon Imperial Pigeon; RFL, Red-flanked Lorikeet; DB, Dollarbird.
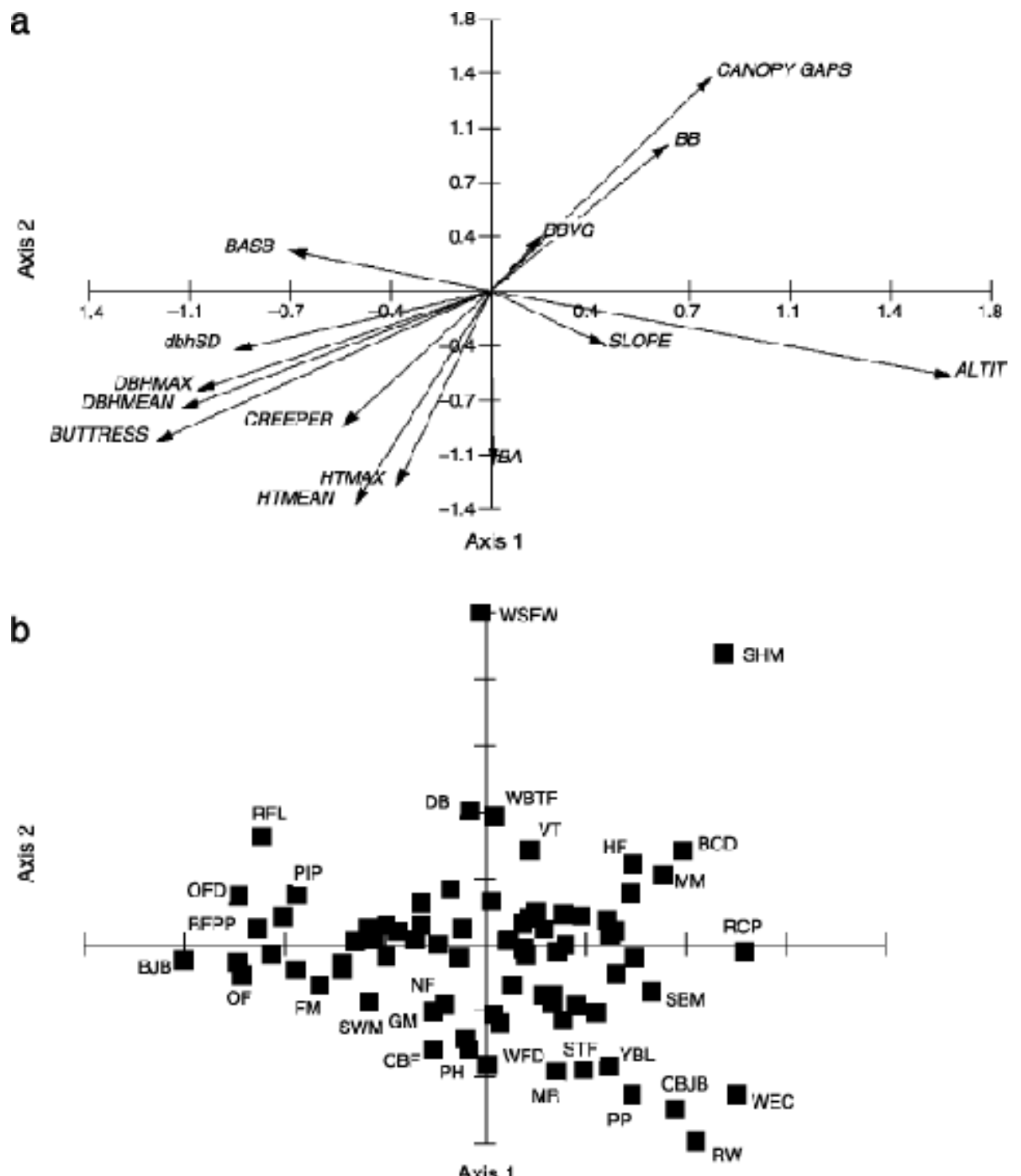

Axis 1 
Table 1. The number of survey plots in each habitat and altitude category.

\begin{tabular}{|c|c|c|c|c|c|}
\hline & \multicolumn{2}{|c|}{ Initial categories } & & \multicolumn{2}{|c|}{ Categories for analysis } \\
\hline & $<650 \mathrm{~m}$ & $>650 \mathrm{~m}$ & & $<650 \mathrm{~m}$ & $>650 \mathrm{~m}$ \\
\hline PRIM & 19 & 19 & Primary forest & 66 & 38 \\
\hline DISTPRIM & 47 & 19 & & & \\
\hline$>20$ YR GARD & 25 & 15 & Old gardens & 34 & 32 \\
\hline 8-20 YR GARD & 9 & 17 & & & \\
\hline 2-8 YR GARD & 9 & 16 & New gardens & 22 & 34 \\
\hline GARD & 13 & 18 & & & \\
\hline
\end{tabular}


Table 2. Results of one-way ANOVAs of vegetation characteristics across plots in different habitat types and altitudinal bands. For mean dbh, cv of dbh and mean height, parametric ANOVAs were used with Tukey's HSD post-hoc tests. For the other habitat parameters, we used non-parametric ANOVAs with Dunn's post-hoc tests. Figures quoted for each habitat parameter are means \pm sd, except for Canopy cover where the median values of assessment scale are given.

\begin{tabular}{|c|c|c|c|c|c|c|c|}
\hline & \multicolumn{3}{|c|}{ Altitudes $=650 \mathrm{~m}$} & \multicolumn{4}{|c|}{ Altitudes $>650 \mathrm{~m}$} \\
\hline & $\begin{array}{c}\text { Primary (A) } \\
n=66\end{array}$ & Old (B) $n=34$ & $\begin{array}{c}\text { New (C) } \\
n=22\end{array}$ & $\begin{array}{c}\text { Primary (D) } \\
n=38\end{array}$ & $\begin{array}{c}\text { Old (E) } \\
n=32\end{array}$ & $\begin{array}{c}\text { New (F) } \\
n=34\end{array}$ & Test result \\
\hline \multirow[t]{2}{*}{ Mean dbh $(\mathrm{cm})$} & $110 \pm 36$ & $74 \pm 27$ & $51 \pm 34$ & $81 \pm 26$ & $62 \pm 21$ & $46 \pm 14$ & $\begin{array}{l}F_{6,220}=302 \\
P<0.001\end{array}$ \\
\hline & $\mathrm{A}>\mathrm{BCDEF}$ & $\mathrm{B}>\mathrm{CF}=\mathrm{DE}$ & $\mathrm{C}<\mathrm{D}=\mathrm{EF}$ & $\mathrm{D}>F=\mathrm{E}$ & $\mathrm{E}=\mathrm{F}$ & & \\
\hline \multirow[t]{2}{*}{$\mathrm{cv}$ of $\mathrm{dbh}$} & $43 \pm 19$ & $41 \pm 18$ & $56 \pm 29$ & $40 \pm 18$ & $41 \pm 22$ & $32 \pm 15$ & $\begin{array}{l}F_{6,220}=171 \\
P<0.001\end{array}$ \\
\hline & $\mathrm{A}=\mathrm{BCDEF}$ & $\mathrm{B}=\mathrm{CDEF}$ & $\mathrm{C}>\mathrm{DF}=\mathrm{E}$ & $\mathrm{D}=\mathrm{EF}$ & $\mathrm{E}=\mathrm{F}$ & & \\
\hline \multirow[t]{2}{*}{ Mean height (m) } & $35 \pm 4.4$ & $26 \pm 6.9$ & $19 \pm 8.4$ & $35 \pm 8.4$ & $29 \pm 8.0$ & $24 \pm 6.8$ & $\begin{array}{l}F_{6,220}=706 \\
P<0.001\end{array}$ \\
\hline & $\mathrm{A}>\mathrm{BCEF}=\mathrm{D}$ & $\mathrm{B}>\mathrm{C}<\mathrm{D}=\mathrm{EF}$ & $\mathrm{C}<\mathrm{DE}=\mathrm{F}$ & $\mathrm{D}>\mathrm{EF}$ & $\mathrm{E}>\mathrm{F}$ & & \\
\hline \multirow[t]{2}{*}{ Canopy cover } & $>80 \%$ & $41-60 \%$ & $<20 \%$ & $60-80 \%$ & $60-80 \%$ & $21-40 \%$ & $\begin{array}{l}H_{5,220}=147 \\
P<0.001\end{array}$ \\
\hline & $\mathrm{A}>\mathrm{BCEF}=\mathrm{D}$ & $\mathrm{B}>\mathrm{C}<\mathrm{D}=\mathrm{EF}$ & $\mathrm{C}<\mathrm{DE}=\mathrm{F}$ & $\mathrm{D}>\mathrm{EF}$ & $\mathrm{E}>\mathrm{F}$ & & \\
\hline \multirow{2}{*}{$\begin{array}{l}\text { Primary forest } \\
\text { architectures }\end{array}$} & $2.8 \pm 1.1$ & $1.8 \pm 1.2$ & $1.3 \pm 1.1$ & $3.5 \pm 1.1$ & $2.8 \pm 1.3$ & $1.6 \pm 1.3$ & $\begin{array}{l}H_{5,220}=64.2 \\
P<0.001\end{array}$ \\
\hline & $\mathrm{A}>\mathrm{BCF}=\mathrm{DE}$ & $\mathrm{B}<\mathrm{DE}=\mathrm{CF}$ & $\mathrm{C}<\mathrm{DE}=\mathrm{F}$ & $\mathrm{D}>F=\mathrm{E}$ & $\mathrm{E}>\mathrm{F}$ & & \\
\hline \multirow{2}{*}{$\begin{array}{l}\text { Regenerating } \\
\text { forest architectures }\end{array}$} & $1.4 \pm 1.0$ & $1.0 \pm 1.0$ & $1.6 \pm 1.0$ & $0.7 \pm 0.8$ & $0.5 \pm 0.7$ & $0.8 \pm 1.0$ & $\begin{array}{l}H_{5,220}=32.9 \\
P<0.001\end{array}$ \\
\hline & $\mathrm{A}>\mathrm{DE}=\mathrm{BCF}$ & $\mathrm{B}=\mathrm{CDEF}$ & $\mathrm{C}>\mathrm{DE}=\mathrm{F}$ & $\mathrm{D}=\mathrm{EF}$ & $\mathrm{E}=\mathrm{F}$ & & \\
\hline
\end{tabular}




\begin{tabular}{|c|c|c|c|c|c|c|c|}
\hline & \multicolumn{3}{|c|}{ Altitudes $=650 \mathrm{~m}$} & \multicolumn{4}{|c|}{ Altitudes $>650 \mathrm{~m}$} \\
\hline & $\begin{array}{c}\text { Primary (A) } \\
n=66\end{array}$ & Old (B) $n=34$ & $\begin{array}{c}\text { New (C) } \\
n=22\end{array}$ & $\begin{array}{c}\text { Primary (D) } \\
n=38\end{array}$ & $\begin{array}{c}\text { Old (E) } \\
n=32\end{array}$ & $\begin{array}{c}\text { New (F) } \\
n=34\end{array}$ & Test result \\
\hline \multirow[t]{2}{*}{ Creeper cover } & $3.9 \pm 0.9$ & $3.9 \pm 1.2$ & $2.0 \pm 1.8$ & $3.9 \pm 1.1$ & $3.6 \pm 1.3$ & $2.7 \pm 1.5$ & $\begin{array}{l}H_{5,220}=36.0 \\
P<0.001\end{array}$ \\
\hline & $\mathrm{A}>\mathrm{CF}=\mathrm{BDE}$ & $\mathrm{B}>\mathrm{CF}=\mathrm{DE}$ & $\mathrm{C}<\mathrm{DE}=\mathrm{F}$ & $\mathrm{D}>F=\mathrm{E}$ & $E=F$ & & \\
\hline
\end{tabular}

Table 3. Summary bird survey statistics. Lower altitudes = survey plots below $651 \mathrm{~m}(432-650 \mathrm{~m})$ and higher altitudes $=651-935 \mathrm{~m}$.

\begin{tabular}{|c|c|c|c|c|c|c|}
\hline & \multicolumn{3}{|c|}{ Lower altitudes } & \multicolumn{3}{|c|}{ Higher altitudes } \\
\hline & Primary & Old gardens & New gardens & Primary & Old gardens & New gardens \\
\hline Number of survey plots & 65 & 36 & 20 & 36 & 31 & 34 \\
\hline Total effort (number of counts) & 128 & 64 & 40 & 66 & 62 & 67 \\
\hline Total number bird records & 1639 & 699 & 480 & 496 & 520 & 498 \\
\hline Observed species richness & 107 & 85 & 78 & 89 & 89 & 69 \\
\hline Estimated species richness (ACE) & 136 & 93 & 98 & 104 & 109 & 84 \\
\hline 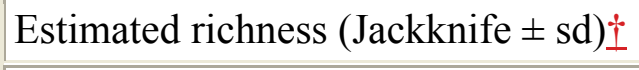 & $134 \pm 5.4$ & $102 \pm 4.5$ & $101 \pm 5.1$ & $113 \pm 5.4$ & $115 \pm 5.0$ & $89 \pm 5.2$ \\
\hline Species exclusive to hab/alt category & 5 & 3 & 12 & 5 & 0 & 2 \\
\hline Mean encounter rate \pm sd (all spp.) & $12.7 \pm 4.8$ & $10.9 \pm 4.4$ & $12.0 \pm 4.3$ & $7.9 \pm 3.5$ & $9.1 \pm 2.7$ & $7.5 \pm 3.4$ \\
\hline
\end{tabular}


Table 4. Density estimates (individuals per $\mathrm{km}^{2}$ ) $\pm \%$ se and $95 \%$ confidence intervals for 31 species recorded $>50$ times. Lower altitudes $=650 \mathrm{~m}(432-650 \mathrm{~m})$ and Higher altitudes $>650 \mathrm{~m}(651-935 \mathrm{~m})$. Nomenclature and sequence follow Beehler $e t$ al. $(1986)$.

\begin{tabular}{|c|c|c|c|c|c|c|}
\hline & \multicolumn{3}{|c|}{ Lower altitudes } & \multicolumn{3}{|c|}{ Higher altitudes } \\
\hline & Primary & Old gardens & New gardens & Primary & Old gardens & New gardens \\
\hline Pink-spotted Fruit-dove & $11.7 \pm 24.4$ & $14.3 \pm 30.1$ & $12.5 \pm 44.1$ & $3.8 \pm 54.7$ & $6.7 \pm 51.9$ & $5.0 \pm 48.7$ \\
\hline Ptilinopus perlatus & $7.3-19$ & $7.9-26$ & $5.2-30$ & $1.3-11$ & $2.5-18$ & $2.0-13$ \\
\hline Superb Fruit-dove & $15.1 \pm 22.5$ & $7.2 \pm 66.9$ & $9.2 \pm 58.5$ & $30.6 \pm 20.0$ & $20.7 \pm 24.9$ & $17.8 \pm 29.0$ \\
\hline P. superbus & $9.7-23$ & $2.1-25$ & $2.9-29$ & $20-46$ & $13-34$ & $10-32$ \\
\hline Beautiful Fruit-dove & $25.5 \pm 11.9$ & $16.2 \pm 23.3$ & $14.3 \pm 38.5$ & $15.9 \pm 29.3$ & $14.3 \pm 28.3$ & $19.3 \pm 23.6$ \\
\hline P. pulchellus & $20-32$ & $10-26$ & $6.6-31$ & $8.9-28$ & $8.1-25$ & $12-31$ \\
\hline Pinon Imperial Pigeon & $15.5 \pm 26.0$ & $18.4 \pm 29.3$ & $22.6 \pm 38.6$ & 0 & $2.9 \pm 102$ & 0 \\
\hline Ducula pinon & $9.4-26$ & $10-32$ & $11-48$ & 0 & $0.5-16$ & 0 \\
\hline Zoe Imperial Pigeon & $8.8 \pm 19.1$ & $9.6 \pm 24.7$ & $7.6 \pm 42.7$ & $25.8 \pm 32.1$ & $33.8 \pm 20.7$ & $39.1 \pm 26.4$ \\
\hline D. zoeae & $6.0-13$ & $5.8-16$ & $3.3-18$ & $14-49$ & $22-51$ & $23-66$ \\
\hline Western Black-capped Lory & $22.8 \pm 34.7$ & $10.1 \pm 50.7$ & $24.3 \pm 41.6$ & $34.6 \pm 49.7$ & $36.8 \pm 45.3$ & $18.9 \pm 54.5$ \\
\hline Lorius lory & $12-44$ & $3.9-26$ & $11-54$ & $14-88$ & $15-88$ & $6.8-52$ \\
\hline Sulphur-crested Cockatoo & $15.1 \pm 17.6$ & $12.4 \pm 16.5$ & $17.9 \pm 25.1$ & $7.8 \pm 37.1$ & $8.3 \pm 33.2$ & $11.1 \pm 26.2$ \\
\hline Cacatua galerita & $11-21$ & $8.9-17$ & $11-30$ & $3.8-16$ & $4.3-16$ & $6.6-19$ \\
\hline Orange-breasted Fig-parrot & $53.4 \pm 17.7$ & $28.2 \pm 35.2$ & $31.5 \pm 43.6$ & $36.2 \pm 38.0$ & $45.0 \pm 41.5$ & $41.6 \pm 36.1$ \\
\hline Cyclopsitta gulielmiterti & $38-76$ & $14-56$ & $13-75$ & $17-76$ & $20-101$ & $21-84$ \\
\hline Eclectus Parrot & $11.2 \pm 40.2$ & $14.0 \pm 40.7$ & $22.4 \pm 39.5$ & $8.1 \pm 48.1$ & $13.0 \pm 43.0$ & $4.0 \pm 64.1$ \\
\hline
\end{tabular}




\begin{tabular}{|c|c|c|c|c|c|c|}
\hline & \multicolumn{3}{|c|}{ Lower altitudes } & \multicolumn{3}{|c|}{ Higher altitudes } \\
\hline & Primary & Old gardens & New gardens & Primary & Old gardens & New gardens \\
\hline Eclectus roratus & $5.2-24$ & $6.4-30$ & $10-48$ & $3.3-20$ & $5.7-29$ & $1.2-13$ \\
\hline Rufous-bellied Kookaburra & $17.2 \pm 28.0$ & $17.2 \pm 37.5$ & $24.8 \pm 42.9$ & $11.7 \pm 51.3$ & $12.4 \pm 44.5$ & $14.8 \pm 38.6$ \\
\hline Dacelo gaudichaud & $10-30$ & $8.3-36$ & $11-57$ & $4.4-31$ & $5.3-29$ & $7.0-31$ \\
\hline Yellow-bellied Kingfisher & $12.8 \pm 26.9$ & $9.1 \pm 47.8$ & $2.9 \pm 100$ & $15.9 \pm 33.6$ & $26.4 \pm 27.1$ & $20.9 \pm 31.3$ \\
\hline Halcyon torotoro & $7.5-22$ & $3.6-23$ & $0.5-17$ & $8.2-31$ & $15-45$ & $11-39$ \\
\hline Dwarf Kingfisher & $33.7 \pm 18.1$ & $36.3 \pm 28.2$ & $12.4 \pm 73.0$ & $7.5 \pm 53.5$ & $13.4 \pm 41.7$ & $9.9 \pm 47.3$ \\
\hline Ceyx lepidus & $24-48$ & $21-64$ & $3.2-49$ & $2.7-21$ & $5.9-30$ & $4.0-25$ \\
\hline Boyer's Cuckoo-shrike & $32.5 \pm 20.1$ & $20.3 \pm 27.9$ & $13.0 \pm 47.5$ & $7.9 \pm 53.0$ & $4.2 \pm 70.6$ & $7.7 \pm 48.8$ \\
\hline Coracina boyeri & $22-48$ & $12-35$ & $5.1-33$ & $2.9-22$ & $1.1-15$ & $3.0-20$ \\
\hline Rusty Mouse-warbler & $33.2 \pm 18.0$ & $12.7 \pm 50.8$ & $10.1 \pm 68.9$ & $39.9 \pm 27.9$ & $26.1 \pm 40.1$ & $21.2 \pm 39.6$ \\
\hline Crateroscelis murina & $23-47$ & $4.8-33$ & $2.8-37$ & $23-70$ & $12-58$ & $9.7-46$ \\
\hline Little Shrike-thrush & $31.8 \pm 15.9$ & $8.0 \pm 44.7$ & $22.6 \pm 101$ & $89.1 \pm 28.6$ & $51.1 \pm 47.5$ & $40.5 \pm 40.7$ \\
\hline Colluricincla megarhyncha & $23-44$ & $3.3-19$ & $3.9-131$ & $51-156$ & $21-127$ & $18-89$ \\
\hline Hooded Pitohui & $70.5 \pm 9.9$ & $58.4 \pm 15.1$ & $45.5 \pm 19.0$ & $11.7 \pm 36.1$ & $29.1 \pm 22.9$ & $21.2 \pm 28.3$ \\
\hline Pitohui dichrous & $58-86$ & $43-79$ & $31-67$ & $5.8-24$ & $18-46$ & $12-37$ \\
\hline Rusty Pitohui & $29.1 \pm 16.4$ & $26.2 \pm 23.9$ & $21.0 \pm 37.8$ & $12.3 \pm 43.1$ & $22.5 \pm 33.6$ & $13.9 \pm 36.2$ \\
\hline Pitohui ferrugineus & $21-40$ & $16-42$ & $9.8-45$ & $5.3-28.4$ & $12-44$ & $6.8-28$ \\
\hline Black Berrypecker & $33.1 \pm 20.6$ & $33.0 \pm 27.5$ & $15.1 \pm 47.0$ & $4.6 \pm 67.4$ & $4.9 \pm 70.2$ & 0.0 \\
\hline Melanocharis nigra & $22-50$ & $19-57$ & $6.0-38$ & $1.3-16$ & $1.3-18$ & $0-0$ \\
\hline Papuan Flowerpecker & $76.3 \pm 31.0$ & $113 \pm 31.5$ & $141 \pm 33.4$ & $28.6 \pm 52.9$ & $35.6 \pm 52.9$ & $18.8 \pm 54.4$ \\
\hline
\end{tabular}




\begin{tabular}{|c|c|c|c|c|c|c|}
\hline & \multicolumn{3}{|c|}{ Lower altitudes } & \multicolumn{3}{|c|}{ Higher altitudes } \\
\hline & Primary & Old gardens & New gardens & Primary & Old gardens & New gardens \\
\hline Dicaeum pectorale & $41-141$ & $62-208$ & $74-270$ & $11-77$ & $14-88$ & $6.8-52$ \\
\hline Black Sunbird & $66.7 \pm 23.5$ & $41.7 \pm 35.9$ & $66.7 \pm 40.8$ & $24.3 \pm 48.7$ & $17.2 \pm 50.5$ & $59.7 \pm 29.2$ \\
\hline Nectarinia aspasia & $42-105$ & $21-84$ & $30-149$ & $9.6-61$ & $6.6-45$ & $34-106$ \\
\hline Long-billed Honeyeater & $18.1 \pm 34.8$ & $47.1 \pm 34.1$ & $23.2 \pm 49.7$ & $38.7 \pm 37.5$ & $33.7 \pm 34.3$ & $20.8 \pm 41.9$ \\
\hline Melilestes megarhynchus & $9.3-35$ & $24-91$ & $8.8-61$ & $19-80$ & $17-66$ & $9.3-47$ \\
\hline Scrub White-eared Meliphaga & $61.5 \pm 13.6$ & $121 \pm 11.3$ & $125 \pm 14.4$ & $25.2 \pm 31.7$ & $68.4 \pm 18.6$ & $70.0 \pm 19.7$ \\
\hline Meliphaga albonotata & $47-80$ & $96-151$ & $93-167$ & $13-47$ & $47-99$ & $47-104$ \\
\hline Tawny-breasted Honeyeater & $86.1 \pm 11.8$ & $77.0 \pm 15.0$ & $87.0 \pm 20.6$ & $54.9 \pm 21.4$ & $72.5 \pm 17.8$ & $110 \pm 15.4$ \\
\hline Xanthotis flaviventer & $68-109$ & $57-104$ & $57-133$ & $36-84$ & $51-104$ & $81-151$ \\
\hline Helmeted Friarbird & $9.3 \pm 18.4$ & $11.0 \pm 20.1$ & $20.4 \pm 19.8$ & $5.1 \pm 39.8$ & $22.9 \pm 28.6$ & $42.4 \pm 21.7$ \\
\hline Philemon buceroides & $6.4-13$ & $7.3-16$ & $14-31$ & $2.3-11$ & $13-40$ & $27-65$ \\
\hline Yellow-faced Mynah & $33.6 \pm 20.8$ & $21.5 \pm 17.6$ & $67.1 \pm 21.8$ & $30.5 \pm 37.1$ & $39.0 \pm 23.3$ & $34.1 \pm 29.3$ \\
\hline Mino dumontii & $22-50$ & $15-31$ & $43-104$ & $15-63$ & $25-62$ & $19-61$ \\
\hline Spangled Drongo & $26.3 \pm 21.9$ & $22.8 \pm 37.8$ & $29.2 \pm 44.0$ & $19.9 \pm 30.4$ & $23.6 \pm 29.4$ & $32.7 \pm 29.9$ \\
\hline Dicrurus hottentottus & $17-40$ & $11-48$ & $12-70$ & $11-36$ & $13-42$ & $18-59$ \\
\hline Hooded Butcherbird & $12.8 \pm 24.7$ & $16.4 \pm 24.1$ & $29.7 \pm 33.3$ & $20.6 \pm 30.8$ & $27.4 \pm 28.0$ & $21.5 \pm 33.6$ \\
\hline Cracticus cassicus & $7.9-23$ & $9.1-35$ & $15-58$ & $11-38$ & $16-47$ & $11-42$ \\
\hline Magnificent Riflebird & $14.1 \pm 26.5$ & $5.7 \pm 42.0$ & $5.2 \pm 71.5$ & $14.9 \pm 32.0$ & $5.8 \pm 44.0$ & 0.0 \\
\hline Ptiloris magnificus & $8.4-24$ & $2.5-13$ & $1.4-20$ & $8.0-28$ & $2.5-14$ & $0-0$ \\
\hline King Bird of Paradise & $64.6 \pm 9.4$ & $31.9 \pm 19.9$ & $28.9 \pm 26.4$ & $5.4 \pm 57.4$ & $27.2 \pm 27.7$ & $15.9 \pm 32.8$ \\
\hline
\end{tabular}




\begin{tabular}{|l|l|l|l|l|l|l||}
\hline \multirow{2}{*}{} & \multicolumn{3}{|c|}{ Lower altitudes } & \multicolumn{3}{c|}{ Higher altitudes } \\
\cline { 2 - 7 } & Primary & Old gardens & New gardens & Primary & Old gardens & New gardens \\
\hline Cicinnurus regius & $54-78$ & $21-47$ & $17-50$ & $1.8-16$ & $16-47$ & $8.3-30$ \\
\hline Magnificant Bird of Paradise & $17.9 \pm 27.4$ & $3.4 \pm 66.8$ & $5.4 \pm 70.1$ & $11.6 \pm 40.3$ & $31.6 \pm 29.5$ & $8.1 \pm 52.2$ \\
\hline C. magnificus & $10-30$ & $1.0-12$ & $1.5-20$ & $5.3-25$ & $18-57$ & $3.0-22$ \\
\hline Raggiana Bird of Paradise & $16.3 \pm 12.4$ & $14.7 \pm 18.0$ & $20.9 \pm 15.8$ & $42.7 \pm 26.0$ & $70.3 \pm 21.0$ & $70.8 \pm 18.9$ \\
\hline Paradisaea raggiana & $13-21$ & $10-21$ & $15-29$ & $26-71$ & $46-106$ & $49-103$ \\
\hline
\end{tabular}

Back to top 